\title{
Review over international forskningslitteratur om digitale læringsplatforme
}

Af Andreas Lindenskov Tamborg, Andreas Riekehr Bjerre og Lars Birch Andreasen, Aalborg Universitet Thomas R.S. Albrechtsen, UC Syd og Morten Misfeldt, Aalborg Universitet

Korrekt citering af denne artikel efter APA-systemet (American Psychological Association System, 6th Edition): Tamborg, A. L., Bjerre, A. R., Andreasen, L. B. \& Misfeldt, M. (2019). Review over international forskningslitteratur om digitale læringsplatforme. Learning Tech - Tidsskrift for læremidler, didaktik og teknologi, (6), 12-31. DOI 10.7146/It.v4i6.110877 


\section{Abstract}

Denne artikel afsøger den seneste internationale engelsksprogede forskningslitteratur om anvendelse af digitale læringsplatforme. Reviewet behandler forskning fra i alt 21 studier og sammenfatter resultaterne i tre hovedkategorier, der henholdsvis omfatter implementering af læringsplatforme, kompetenceudviklingsbehov i forbindelse med platforme og relationen mellem elevers brug af platforme og deres faglige udbytte. Reviewet afsluttes med en diskussion af, hvordan resultaterne af litteraturgennemgangen kan have relevans for en dansk uddannelseskontekst i forhold til særlige opmærksomhedspunkter i den pædagogiske praksis, forskning og beslutningstagning.

The article is a review of current international research literature on the use of digital learning platforms in educational settings. The review includes a total of 21 studies and summarizes the results in three main categories: 1 . Support of students' learning and performance, 2. implementation of digital learning platforms, and 3. competence development of instructors. The relevance of the results in a Danish educational context is discussed in relation to educational practice, research and decision making. 


\section{Review over}

international

forskningslitteratur om digitale læringsplatforme

\section{Indledning}

Implementeringen af digitale læringsplatforme i de danske folkeskoler er ikke et enestående initiativ, der forsøger at forbedre skole og uddannelse ved hjælp af de muligheder, der er forbundet med nye teknologiske landvindinger. Over store dele af verden er der i de senere år sket en vækst af tiltag i uddannelsessektorer i forhold til indkøb og implementering af digitale platforme eller andre lignende teknologier. Meget tyder på, at denne udvikling fortsat vil accelerere i de kommende år (Johnson, Adams Becker \& Hall, 2015). En af årsagerne til denne udvikling er, at teknologier som digitale læringsplatforme ofte associeres med forhåbninger om at øge elevers læring (Edmunds \& Hartnett, 2014; Lu \& Law, 2012; Psycharis, 2013), effektivisere læreres arbejde (KL, Undervisningsministeriet, Finansministeriet \& Ministeriet for Børn, Ligestilling, Integration og Sociale Forhold, Økonomi- og Indenrigsministeriet, 2014; Johansson \& Glauman, 2014) og understøtte lærere i kollaborativt at producere, dele og videreudvikle undervisningsmaterialer (Gueudet, Pepin, Sabra \& Trouche, 2016).

Den stigende anvendelse af teknologier som digitale læringsplatforme, har betydet, at der efterhånden er akkumuleret en række studier af empirisk baseret videnskabelig viden om, dels hvilke potentialer digitale læringsplatforme besidder, og hvilke udfordringer der er relateret til at udnytte disse. Især i en dansk kontekst, hvor den igangværende implementering af læringsplatforme omfatter alle landets folkeskoler, anser vi dette for et vigtigt vidensfundament at have kendskab til. Formålet med denne artikel er således at danne et overblik over resultaterne og indsigterne i den internationale litteratur om digitale læringsplatforme. Et sådant overblik vil være anvendeligt både for forskere og prakti- 
kere, der beskæftiger sig med området. For forskere skaber det et informationsgrundlag, som nye forskningsprojekter kan bygge videre på, og for praktikere kan indsigter fra litteraturen anvendes til at informere og kvalificere beslutningsprocesser i forbindelse med implementering og ibrugtagning. Artiklen er således rettet mod at besvare følgende forskningsspørgsmål:

Hvilke tematikker, potentialer og faldgruber diskuteres i den internationale litteratur om digitale læringsplatforme? Og hvordan og i hvilket omfang kan dette kvalificere fremtidig forskning i og praksis med digitale læringsplatforme i dansk kontekst?

Inden vi besvarer dette spørgsmål, vil vi redegøre for reviewprocessen i form af søgning, screening af artikler og udvælgelseskriterierne. Dernæst vil vi beskrive reviewets fund i forhold til de tematikker, vi identificerede i reviewets artikler. Artiklen afsluttes med en diskussion af, hvordan og i hvilket omfang reviewets fund kan kvalificere fremtidig forskning i og praksis med digitale læringsplatforme i en dansk kontekst.

\section{Metode}

Litteraturen i reviewet er udvalgt gennem en systematisk litteratursøgning, som er foretaget i den åbne database ERIC (Education Resources Information Center; https://eric.ed.gov), som er den førende database over engelsksproget litteratur specifikt relateret til forskning på uddannelsesområdet. I litteraturen går det, vi på dansk forstår ved digitale læringsplatforme, under mange navne (Watson \& Watson, 2007). For at indfange så mange relevante studier som muligt i søgeprocessen, afgrænsede vi en række forskellige, relevante nøglebegreber relateret til reviewets område, som søgningen er gennemført ud fra. Disse nøglebegreber omfattede: 
— Learning platforms

— Learning management system

- LMS

— Virtual learning environments

— Digital learning environments

- Course management systems

— Electronic learning environments

Søgningen med disse søgeord ledte til i alt 73 artikler. De 73 artikler blev screenet ad to omgange - først på titel - og dernæst på abstract-niveau. I begge screeninger var selektionskriterierne, at enten artiklernes genstandsfelt eller resultater skulle være eksplicit relateret til digitale læringsplatforme. Desuden prioriterede vi, at artiklerne skulle have fokus på enten grundskoleeller gymnasieniveau, for at artiklernes resultater og kontekster skulle komme så tæt på den danske situation som muligt. Denne prioritering medførte, at studier, der relaterede sig til universitetssammenhænge, blev fravalgt. Screeningen efterlod os med i alt 21 artikler, som udgør vidensfundamentet for denne artikel. De 21 artikler er markeret med $\left(^{*}\right)$ i referencelisten.

Efter artiklerne var udvalgt, foretog vi en systematisk gennemlæsning af studierne med henblik på at syntetisere de overordnede tematikker, som artiklernes resultater kunne opdeles i. Denne proces ledte til identifikationen af følgende tematikker:

1. Digitale læringsplatformes understøttelse af elevers læring

2. Implementering af digitale læringsplatforme

3. Kompetenceudvikling af pædagogisk personale i forhold til brugen af digitale læringsplatforme

I det følgende vil vi præsentere resultatet fra reviewet ud fra disse tre kategorier, hvilket vil lede til en diskussion af, hvordan resultaterne af reviewet kan have relevans for en dansk uddannelseskontekst i forhold til særlige opmærksomhedspunkter i den pædagogiske praksis, forskning og beslutningstagning.

\section{Understøttelse af elevers læring}

\section{Elevers læringsudbytte}

En af forhåbningerne associeret med de danske digitale læringsplatforme er, at de kan understøtte elevers læring (KL, 2016).

Digitale læringsplatforme har ofte funktioner, der muliggør on- 
line synkrone eller asynkrone informationsudvekslinger mellem lærere og elever via eksempelvis elektronisk opgaveaflevering, digitale logbøger eller chatlignende services, som læreren har adgang til at se, og en del af litteraturen om digitale læringsplatforme undersøger mulighederne for at anvende sådanne funktioner til at understøtte elevers læring (Edmunds \& Hartnett, 2014; Lu \& Law, 2012; Psycharis, 2013). Et af studierne peger især på potentialerne i elevproducerede logtekster, hvor elever kan nedfælde refleksioner over deres aktiviteter og over de udfordringer, de løbende møder i arbejdet med at løse opgaver. Edmunds og Hartnett (2014) fremhæver, at dette skaber en øget mulighed for at dele informationer gennem digitale læringsplatforme, hvilket kan give lærere et værdifuldt indblik i elevers aktuelle niveau og udfordringer. En af de fordele, forfatterne fremhæver ved denne mulighed, er, at den skaber bedre betingelser for, at lærere kan tilrettelægge og gennemføre differentieret undervisning (Edmunds \& Hartnett, 2014). Studiet påpeger også, at læreres muligheder for at kommentere uploadede opgavebesvarelser skaber gunstige betingelser og understøtter løbende feedback og feedforward (Edmunds \& Hartnett, 2014).

Et andet studie har beskæftiget sig med at undersøge relationen mellem elevers deltagelse i "peer assessment"-aktiviteter, medieret via digitale læringsplatforme, og deres læringsudbytte målt på opnåede karakterer, efter forløbet var gennemført (Lu \& Law, 2012). Ifølge dette studie er der sammenhæng mellem omfanget af elevernes deltagelse i peer assessment-aktiviteterne i platformene, målt på antal af kommentarer til andre elevers arbejde samt antal redigeringer i andre elevers wikier og den karakter, eleverne fik for deres arbejde (Lu \& Law, 2012). Digitale læringsplatforme giver også lærere mulighed for at udvikle undervisningsforløb, der præsenterer elever for fagligt indhold gennem flere forskellige modaliteter (fx tekst, billeder, videoer, tabeller og figurer) (Psycharis, 2013). Et af studierne har undersøgt elevers oplevelse af et fysikforløb, hvor de forskellige modaliteter blev anvendt i formidlingen af fagligt indhold (Psycharis, 2013). Dette studie viste, at eleverne oplevede, at brugen af flere modaliteter i undervisningsforløb om fysiske fænomener gjorde det lettere for dem at forstå ellers komplekst fagligt indhold (Psycharis, 2013).

En anden fordel ved digitale læringsplatforme, som fremhæves i litteraturen, er, at elever kan få et digitalt rum i en skolekontekst, hvor de selv har mulighed for at personalisere layout 
og indhold (Camacho \& Guilana, 2011; Johnson, Adams Becker \& Hall, 2015). Et af de interessante fund ved Camacho og Guilanas (2011) studier er, at de fremhæver muligheden for både at styrke fællesskabet og øge elevers læring gennem gruppevise dialogbaserede samtaler, der tager udgangspunkt i elevers eget personaliserede digitale rum. Dette fund er interessant, fordi netop den personaliserende dimension ved digitale læringsplatforme længe har været fremført som en af styrkerne ved digitale teknologier (Pogorskiy, 2015), men også har været anklaget for at accelerere en individualiseret skolekultur på bekostning af fællesskabet (Biesta, 2011). Camacho og Guilanas (2011) studie bidrager med en vigtig nuancering af denne diskussion og viser, at henholdsvis individualiserende og fællesskabsprioriterende undervisning ikke i sig selv kan tilskrives de teknologier, vi anvender i undervisning, men snarere måden de anvendes på.

\section{Anvendelse}

Muligheden for, at digitale læringsplatforme kan understøtte elevers læring, afhænger naturligvis både af, i hvilket omfang og hvordan elever bruger platformene og de aktiviteter, der medieres gennem dem. Måske af denne årsag behandler en stor del af de identificerede artikler om elevers arbejde med digitale læringsplatforme hvilke faktorer, der har betydning for elevers oplevede nytteværdi og indstilling over for platformene. En anden årsag til denne interesse kan findes i, at der tilsyneladende er en generel tendens til, at eleverne er vanskelige at motivere til at anvende digitale læringsplatforme, hvilket bl.a. tilskrives det forhold, at platformene opleves som teknisk besværlige (McGill \& Hobbs, 2008). Et studie af Liu og Cavanaugh (2011) viser eksempelvis, at den mest signifikante faktor i forhold til elevernes læringsudbytte, målt på karakterer, er den tid, elever bruger i et LMS. Liu og Cavanaugh peger af denne årsag på, at læringsplatforme skal designes på måder, så elever motiveres til at bruge dem, og at dette bedst opnås ved at sikre brugervenlige og attraktive brugerflader (Liu \& Cavanaugh, 2011). Denne pointe understøttes af Friedrich og Horn (2010), der også fremhæver elevers oplevede nytteværdi som en signifikant positiv indikator for elevernes modtagelse, mens faktorer som både elevers generelle holdning til computere og køn viser sig at have en meget lille eller ingen betydning.

Flere af studierne nuancerer imidlertid den pointe, at omfanget af elevers anvendelse af digitale læringsplatforme er re- 
lateret til brugerfladen alene. Bl.a. fremføres betydningen af forældres indstilling til platformene (Nasser, Cherif, \& Romanowski, 2011), og at desto større opbakning til at bruge platformen, eleverne har fra hjemmet, desto mere gør eleverne brug af dem. Eleverne var desuden mere motiverede for at bruge platformen, når lærerne byggede aktiviteter op omkring den. Studiet viser også det interessante forhold, at elever ikke nødvendigvis finder det let at bruge platformene, selvom de på daglig basis benytter sig af IKT i forskellige afskygninger. Studiet viser, at elevers indstilling til platformene er af væsentlig betydning for omfanget af deres brug af dem, og den negative indstilling til platformen hos eleverne fra dette studie bliver især tilskrevet en oplevelse af, at læringsplatforme ikke bidrager til at øge deres læring, og at tekniske nedbrud resulterede i mistede data (Nasser et al., 2011). Studiet viser således, at både elementer i og uden for platformene har betydning for elevernes indstilling til dem. Denne pointe understøttes af Psycharis (2013), der fremhæver faktorer såsom elevers generelle syn på skolen og deres læreres måde at anvende platformene på som faktorer, der har betydning for elevers oplevede nytteværdi og brugervenlighed af platformen. Bl.a. er der tegn på, at læreres entusiasme over for digitale læringsplatforme kan have positiv betydning for elevers motivation og lyst til at bruge dem (Blair \& Godsall, 2006).

Et andet studie (Tay, Lim, Nair \& Lim, 2014), undersøger elevers brugsmønstre og påvirkning heraf på elevers læring i forbindelse med bl.a. digitale læringsplatforme (men også blogs, online uddannelsesspil og kommunikationsapplikationer) over en periode på to år. Dette studie viser, at omfanget af elevernes brug af alle de undersøgte IKT'er var højest lige efter, de blev implementeret, og at anvendelsen af dem aftog, efter de havde været anvendt 1 år (Tay et al., 2014). Platforme viste sig bemærkelsesværdigt at være den teknologi, hvis anvendelse aftog kraftigst. Det kan altså være vigtigt at være opmærksom på, at elevers motivation til at bruge platforme efter en nylig implementering kan være en effekt af nyhedsværdien, og at der derfor løbende skal arbejdes med at opretholde motivationen.

\section{Implementering}

I de udvalgte studier om digitale læringsplatforme optræder tilgange og udfordringer relateret til implementering som en central tematik. Vi identificerede to hovedkategorier under 
denne tematik: Dels aktørers oplevede bekymringer i forbindelse med implementering af digitale platforme (Lochner, Conrad \& Graham, 2015; Selwyn, 2011; Underwood \& Stiller, 2014), og dels brugeres accept af og tilfredshed med brug af læringsplatformene (De Smet, Bourgonjon, De Wever, Schellens \& Valcke, 2012; Granic \& Cukusic, 2011; Hamdy, 2013; Selwyn, Banaji, Hadjithoma-Garstka \& Clark, 2011). Mens afsnittet om læringspotentialer overvejende fokuserede på elevers anvendelse og oplevelse af læringsplatforme, behandler dette afsnit hovedsageligt implementering af læringsplatforme set fra perspektiver fra henholdsvis pædagogisk personale og skoleledelse.

\section{Bekymringer}

I flere af studierne i dette review fremgår bekymringer blandt aktører involveret i kommende eller igangværende implementeringer af digitale læringsplatforme som et tilbagevendende tema. Et af disse studier er gennemført af Lochner, Conrad og Graham (2015), der undersøger bekymringer blandt lærere i secondary school (svarende til de danske ungdomsuddannelser) i forbindelse med en forestående implementering af en digital læringsplatform. Baseret på et survey undersøger artiklen, hvilke bekymringer lærere oplever i forbindelse med den forestående implementering. Lærerne i dette studie oplevede, at de ikke var blevet informeret tilstrækkeligt om den kommende implementeringsproces, og at de desuden havde meget ringe mulighed for at have indflydelse på, hvordan den skulle forløbe. Disse to forhold var kilden til hovedparten af lærernes bekymringer relateret til implementeringsprocessen. Lærerne udtrykte også bekymringer for, hvorvidt de ville have den fornødne tid til rådighed til at indarbejde de digitale platforme som en integreret del af deres professionelle virke. På grund af den manglende information om implementeringsprocessen gav lærerne også udtryk for en grundlæggende usikkerhed om, hvilke ændringer platformene reelt ville medføre, og hvilken betydning de ville få for deres arbejdsliv. I forlængelse heraf udtrykker lærerne også bekymringer for, om de i tilstrækkelig omfang får mulighed for at tilegne sig viden om platformens funktioner og om samspillet mellem platformen og deres eksisterende forpligtelser (Lochner et al., 2015).

Et studie af Selwyn fremhæver også bekymringer blandt skolepersonale som en væsentlig faktor i forbindelse med implementering af læringsplatforme. Dette studie fokuserer imidlertid ikke kun på bekymringer, der kan opstå blandt pædagogisk 
personale, men inddrager også bekymringer blandt ledelse og administrativt personale. Lærernes bekymringer i dette studie var især relateret til en oplevelse af, at platformen medførte en standardiseret tilgang til undervisning snarere end at understøtte professionel frihed og dømmekraft (Selwyn, 2011). Oplevelsen blandt lærerne var desuden, at platformen hovedsageligt understøttede produktion af data om, hvad der sker, og i mindre grad data, der kunne understøtte selve læringsprocessen. Blandt skoleledelsen finder studiet på den ene side en oplevelse af, at digitale læringsplatforme understøtter etableringen af sofistikeret indsamling og bearbejdning af data (Selwyn, 2011). På den anden side udtrykte skolelederne bekymringer relateret til, at implementering af platformene markerede et øget fokus på effektivitet, måldrevet overvågning, accountability og reduktion af udgifter (Selwyn, 2011).

Også Underwood og Stiller (2014) beskæftiger sig med læreres bekymringer i forhold til brug af digitale læringsplatforme i et studie, der kortlægger barrierer for læreres brug heraf. Ifølge dette studie forbinder lærere de digitale læringsplatforme med en oplevet øget arbejdsbyrde, og studiet viser tendens til, at lærere fravælger at bruge platformen, hvis de vurderer, at den enten er for tidskrævende eller ikke har nogen funktionel eller nogen epistemisk værdi (Underwood \& Stiller, 2014).

\section{Accept og tilfredshed}

En anden gennemgående tematik i den afsøgte litteratur omhandler læreres accept af og tilfredshed med digitale læringsplatforme. Et af disse studier (De Smet et al., 2012) finder, måske ikke så overraskende, at den oplevede nytteværdi, platformens brugervenlighed og den enkelte lærers personlige erfaringsgrundlag er nogle af de mest signifikante faktorer for læreres accept af platformen. Studiet finder også, at både omfanget af og måden, platformene anvendes (og kan anvendes) til at lagre og finde informationer og kommunikere med lærere og elever, har betydning for dette aspekt. Et af studiets øvrige fund er, at disse faktorer ikke kan isoleres fra hinanden, men påvirker hinanden gensidigt. Studiet af Underwood og Stiller (2014) har det interessante fund, at læreres anvendelse af digitale læringsplatforme ikke korrelerer med deres viden om dem. Ifølge Underwood og Stiller kan dette tilsyneladende paradoks forklares ved, at lærere med stor viden om platformen fravælger den, fordi de oplever, at den medfører en øget arbejdsbyrde og ikke nødvendigvis fører en 
reel brugsværdi med sig. Studiet konkluderer på den baggrund, at lærerens viden om digitale læringsplatforme ikke er en afgørende faktor, og at en øget viden om platformene ikke nødvendigvis medfører øget brug af dem. Snarere er lærernes oplevelse af platformens brugsværdi og den oplevede arbejdsbyrde mere væsentlige faktorer for deres brug af den (Underwood \& Stiller, 2014).

Foruden at være en selvstændig teknologi kan nogle typer af digitale læringsplatforme anvendes til at distribuere og udvikle undervisningsmaterialer. Et af de identificerede studier (Hamdy, 2013) påpeger, at design af aktiviteter medieret eller distribueret gennem digitale læringsplatforme bør gøre det muligt for både lærere og elever at få hjælp til at udvikle og anvende aktiviteter, der passer til teknologien, den individuelle pædagogiske tilgang, det valgte indhold, elevernes læringsstile og e-læringskonteksten (Hamdy, 2013). Studiet fremhæver således, at digitale læringsplatforme bør stille både lærere og elever et didaktisk handlerum til rådighed, der gør det muligt at tilpasse forløb og aktiviteter til lokale kontekster, hvis platforme skal kunne adopteres hensigtsmæssigt af både lærere og elever.

De danske digitale læringsplatforme er kendetegnet ved i udgangspunktet at skulle bruges i alle fag på alle årgange. Et af de forhold, der er af betydning i den sammenhæng er, at der er forskel på elevers tilfredshed og anvendelse af læringsplatformen afhængig af alder. Ifølge Granic og Cukusics (2011) brugerevaluering af en e-læringsplatform implementeret i 14, europæiske lande er der tendens til, at de ældste elever er mindst tilfredse med platformen. Ifølge studiet har denne gruppe elevers vurdering af platformens interface og design tilsyneladende den største betydning for deres overordnede vurdering af platformen (Granic \& Cukusic, 2011). Hvad angår lærerne, der deltog i denne brugerevaluering, finder studiet meget lignende resultater, nemlig at lærernes bedømmelse af interfacedesignet og platformens overordnede koncept er af stor betydning for deres bedømmelse af systemet. Samtidig fremhæver studiet, ikke overraskende, at tiden, som det tog lærere at udføre nøgleopgaver i systemet, havde stor betydning for deres overordnede tilfredshed (Granic \& Cukusic, 2011).

Foruden skolepersonale og elever er elevernes forældre også en aktør, der kan involveres i deres børns skolegang gennem læringsplatforme. Et studie af Selwyn, Banaji, Hadjithoma-Garstka og Clark (2011) undersøger, hvordan en digital læringsplatform 
kan hjælpe skoler til at øge forældres engagement i deres børns skolegang. Dette studie viser tendenser til, at digitale læringsplatforme forstærker rutiner i den eksisterende kontakt mellem skole og forældre og altså ikke leder til etablering af nye praksisser. Studiet fremhæver desuden, at platformen hovedsageligt bliver anvendt til envejskommunikation (deling af information, lektier, fremmøde m.m.) fra lærer til forældre (Selwyn et al., 2011).

\section{Kompetenceudvikling}

Foruden de ovenfor nævnte udfordringer forbundet med implementering af digitale læringsplatforme fremhæver flere studier behovet for efteruddannelses- og kompetenceudviklingstiltag, hvis de digitale læringsplatforme skal have en gavnlig effekt for undervisning og elevers læring. Dette behov kan betragtes i lyset af fundene beskrevet i afsnittet om elevers læring, der viste, at det ikke er platformene i sig selv, men de måder de didaktiseres på, der kan være værdifuld. Litteraturen om kompetenceudvikling i forbindelse med digitale læringsplatforme beskæftiger sig dels med denne tematik gennem undersøgelser og beskrivelser af det vidensgrundlag og den professionsfaglige kapacitet, som velovervejet og reflekteret anvendelse af digitale læringsplatforme forudsætter (Abar \& Barbosa, 2011; Nokelainen, 2006), og dels med de forskellige former for efteruddannelsestiltag, der kan benyttes for at skabe disse faglige forudsætninger (Abar \& Barbosa, 2011; Blair \& Godsall, 2006; Cano \& Garcia, 2013; Papadakis, Dovros, Paschalis \& Rossiou, 2012). I det følgende vil vi udfolde, hvordan litteraturen forholder sig til disse tematikker.

\section{Vidensgrundlag}

En af fordelene ved digitale læringsplatforme er, at digitale læremidler bliver lettere at tilgå (Nokelainen, 2006). Digitalt forlagsproduceret undervisningsmateriale kan fx let integreres og tilgås i de fleste platforme, og da lærere også har mulighed for at producere deres eget materiale, som de kan dele med andre, skabes der hele tiden flere ressourcer, som lærere har relativt let adgang til. Forøgelsen af tilgængelige digitale ressourcer betyder imidlertid også, at vurderingen og udvælgelsen af digitale læremidler bliver en stadig vigtigere kompetence at være i besiddelse af som lærer. Ikke alene handler det om at vurdere kvaliteten af materialer, men lærere skal også være i stand til at udvælge den eller de di- 
gitale læremidler, der passer til elevsammensætningen og de ønsker og mål, læreren måtte have for et givent forløb (Nokelainen, 2006). For at understøtte lærere i at træffe kvalificerede valg blandt de mange tilgængelige digitale undervisningsmaterialer har Nokelainen (2006) udviklet en række pædagogisk funderede selektionskriterier, som lærere kan anvende i deres udvælgelse af materialer. Disse kriterier omfatter elevens mulighed for at have kontrol over aktiviteten, hvilke typer af aktiviteter, den lærende engageres $i$, i hvilket omfang undervisningsmaterialet inviterer til kooperativ eller kollaborativ læring, hvor klart målet for aktiviteten fremgår for eleven, omfanget og karakteren af indbyggede differentieringsmuligheder i aktiviteten og muligheden for, at eleven kan få hurtig feedback af god kvalitet (Nokelainen, 2006). Nokelainen (2006) understreger desuden, at anvendeligheden af digitale læringsplatforme bør vurderes ud fra, hvilke undervisningsmaterialer den gør brugeren i stand til at producere.

Også Abar og Barbosa (2011) understreger, at digitale læringsplatforme kan medføre ændringer i undervisningen, som stiller krav til læreres videns- og kompetencegrundlag. Foruden teknisk viden og færdigheder fremhæver dette studie, at anvendelse af platforme kan medføre forskydninger i lærer-elev og elev-elev relationer (Abar \& Barbosa, 2011). I arbejdet med digitale læringsplatforme skal lærere interagere med elever gennem teknologier, og lærere kan let føle sig som begyndere i forhold til deres elever, der er vokset op med daglig brug af computere, tablets og iPhones (Abar \& Barbosa, 2011). Det betyder, at grundlaget for læreres autoritet kan ændres, da det ikke er givet, at lærerne er eksperter og eleverne novicer. Studiet peger på, at læreres kapacitet til at håndtere sådanne forskydninger er tæt relateret til læreres erfaring (Abar \& Barbosa, 2011), hvilket betyder, at lærere ikke nødvendigvis kan rustes til at håndtere dette gennem kurser rettet mod at lære systemet at kende.

\section{Efteruddannelse}

I litteraturen er der bred enighed om vigtigheden af at prioritere kurser og uddannelse af lærere rettet mod at udstyre lærere med viden om den platform, de skal anvende (Abar \& Barbosa, 2011; Blair \& Godsall, 2006; Cano \& Garcia, 2013; Papadakis et al., 2012). Disse studier peger samtidig på en relation mellem læreres viden om platforme og omfanget og måden, hvorpå de anvender dem i deres undervisning.

Bl.a. understreger Papadakis et al. (2012) i lighed med 
Nokelainens (2006) pointe ovenfor, at digitale læringsplatforme ikke tilbyder færdige undervisningstilgange eller undervisningsmaterialer og måder at anvende dem på, og de fremhæver, at de pædagogiske implikationer af dette bør overvejes, hvilket både kræver viden om platformenes funktionalitet og om, hvordan de kan didaktiseres. Litteraturen indeholder et væld af forskellige tilgange, der kan anvendes til at opbygge denne viden, heriblandt workshops (Papadakis et al., 2012), onlinekurser (Abar \& Barbosa, 2011) eller længerevarende efteruddannelsesforløb (Blair \& Godsall, 2006). En af de diskussioner, der synes at være gennemgående i studierne inden for denne tematik, er, i hvilket omfang lærere skal inddrages i diskussioner om, hvad det er vigtigt at kunne for at undervise med de digitale læringsplatforme, og dermed også, hvad det specifikke indhold på kursus- og efteruddannelsesaktiviteterne skal være.

I en workshopbaseret efteruddannelse (Papadakis et al., 2012) blev workshoppens indhold udvalgt på baggrund af lærernes spørgeskemabesvarelser af, hvad de havde behov for, for at kunne blive fortrolige med platformen. Denne tilgang involverede således lærerne direkte i beslutninger om, hvad indholdet på workshoppen skulle være, og på den baggrund blev der anvendt undervisere med specialiseret viden om netop det, lærerne efterspurgte. På et online-kursus derimod (Abar \& Barbosa, 2011) blev indholdet og tilrettelæggelsen af kurset udarbejdet uden involvering af lærerne, men på baggrund af, hvad instruktørerne på kurset fandt vigtigt. En af de væsentlige prioriteringer i dette forløb var at skabe situationer, hvor lærerne kunne få konkrete hands-on erfaringer med platformen. Det var især til opgaver af rutinekarakter såsom at dele opgaver med eleverne og kommunikere i platformens forum (Abar \& Barbosa, 2011).

Blair og Godsall (2006) anvendte en lignende tilgang, hvor underviserne udarbejdede en prioriteret liste over de centrale funktioner i systemet, som de mente, lærerne skulle erhverve sig kendskab til for at kunne arbejde i platformen, særligt i forhold til en e-porteføljefunktion. Disse funktioner blev derefter prioriteret af underviserne efter en vurdering af, hvad der ville lede til en effektiv implementering. Efteruddannelsen af lærerne blev inddelt i fortløbende dele efter en såkaldt "show, practice, run, do"-tilgang. Der er således flere eksempler på tilgange til efteruddannelse af lærere, hvor lærernes synspunkter og oplevede behov enten slet ikke eller kun i meget begrænset omfang tages i betragtning. 
I litteraturen fremhæves det også, at digitale læringsplatforme kan medføre efteruddannelsesbehov og kompetenceløft hos andre end blot de lærere, der bruger dem til daglig (Cano \& Garcia, 2013). I de tilfælde, hvor læreres udvikling løbende understøttes gennem faglig vejledning, er der behov for, at pædagogiske it-vejledere har solid viden om pædagogisk og didaktisk anvendelse af platforme og IKT generelt, og at vejledere ofte ikke har de fornødne kvalifikationer til at understøtte lærere, der arbejder i og med digitale miljøer som en del af deres undervisning (Cano \& Garcia, 2013).

\section{Diskussion}

Vi indledte denne artikel med at påpege, at der internationalt ses initiativer, der på nogle områder minder om implementeringen af de digitale læringsplatforme i Danmark. I det følgende vil vi diskutere anbefalinger til praksis, der ligger i forlængelse af dette reviews resultater. Dernæst vil vi diskutere mulighederne og begrænsningerne ved fundene i studierne i dette review set i lyset af forskellen mellem den danske situation og de kontekster, som reviewets studier er gennemført i.

Der er flere forhold ved den danske situation, der adskiller sig fra de fleste af de kontekster, som forskningsresultaterne om digitale læringsplatforme er genereret inden for i de øvrige lande. Initiativet, der ligger til grund for implementering af de danske digitale læringsplatforme, nemlig Brugerportalsinitiativet, udstikker rammerne for en national løsning, der er obligatorisk for alle danske kommuner. I modsætning til en stor del af de øvrige studier inkluderet i dette review, er beslutningen om at implementere platforme ikke truffet af den enkelte skole eller kommune. For en del af studierne i reviewet implementeres og anvendes digitale læringsplatforme derimod på uddannelsesinstitutionens eget initiativ med et bestemt mål for øje. For en del af de danske skoler og kommuners vedkommende er processen nærmere omvendt, nemlig at løsningen er givet, og at det derefter er op til de enkelte skoler og kommuner at afgøre, hvordan og med hvilke mål for øje, platformene skal anvendes. Dette forhold skaber væsentlige udfordringer for implementeringsprocessen.

Overordnet tegner litteraturen om relationen mellem elevers læring og brug af platforme et billede af, at platforme medfører nye muligheder for at understøtte elevers læreprocesser. Studierne viser især, at platformenes funktioner til informa- 
tionsdeling kan understøtte elev-elev og lærer-elev interaktioner, hvilket i litteraturen fremhæves som en værdifuld funktion, der kan indgå i og kvalificere undervisningsaktiviteter. Selvom studierne tilskriver disse øgede læringsmuligheder funktioner i de digitale platforme, viser litteraturen ikke, at brug af digitale læringsplatforme i sig selv hverken kan eller vil medføre et øget læringsudbytte hos elever. I alle de nævnte eksempler i litteraturen anvendes udvalgte funktioner i platforme til at indgå i og understøtte elementer af en i forvejen didaktisk eller didaktiseret aktivitet som $\mathrm{fx}$ peer assessment, elevers logføring eller læreres systematiske arbejde med feedback og feedforward, hvor platformens funktioner aktivt indtænkes som et understøttende redskab i aktiviteten. Ligesom det tidligere er fremført i studier om digitale læremidler, tilfører digitale læringsplatforme således kun en værdi til undervisning og elevers udbytte under forudsætning af, at de didaktiseres og anvendes med et reflekteret og med et bevidst formål (Bundsgaard, 2010; Johansson \& Glauman, 2014).

Studierne inden for tematikken om digitale læringsplatforme og elevers læring peger dog også på en række centrale udfordringer i forhold til at udnytte de potentialer, der er forbundet med digitale læringsplatforme, selvom de didaktiseres. Et af de mere overraskende fund er, at elevers motivation til at anvende platforme fremstår som en kompleks og sammensat størrelse og ikke kan tages for givet. Her viser litteraturen vigtige indsigter i, at elevers motivation ikke alene er betinget af platformenes interface, brugervenlighed og oplevede nytteværdi, men at faktorer uden for både platformene (fx læreres måde at bruge dem på) og skolen ( $\mathrm{fx}$ forældrenes indstilling til platforme) også kan have stor betydning. En af konsekvenser heraf er, at elevers motivation til at bruge platformene bør fremmes gennem brede indsatser, der foruden eleverne selv også involverer skolens lærere, elevernes forældre og om muligt platformsudviklere. Selvom der er belæg for at gøre sig forhåbninger om, at digitale læringsplatforme kan forøge elevers læringsudbytte, er det således hverken en effekt, der indfrier sig selv, eller som er enkel at udnytte.

I litteraturen er det bredt anerkendt, at forestående og igangværende implementeringer af digitale læringsplatforme fremkalder bekymringer blandt aktører på skoler, og at sådanne bekymringer er meget væsentlige at være opmærksomme på, hvis en succesfuld implementering af digitale platforme skal opnås. Det er imidlertid vigtigt at bemærke, at en stor del af de 
identificerede usikkerheder og bekymringer ser ud til at være relateret til mangelfuld eller dårlig kommunikation om, hvilke ændringer teknologien vil medføre. Som det også fremføres af et af studierne (Lochner et al., 2015), kan en del af disse udfordringer imødekommes gennem en højere grad af transparens i beslutningsprocessen, gennem bedre information om implementeringsprocessen og ved at give det pædagogiske personale indflydelse på implementeringsprocessen (Lochner et al., 2015).

Fokus i studierne relateret til efteruddannelsesformer har hovedsageligt været at beskrive de forskellige måder, hvorpå efteruddannelsesaktiviteter rettet mod en læringsplatform kan designes, og måder, hvorpå lærere kan involveres og ikke involveres i disse design. På baggrund af studierne er det således ikke muligt at slutte, at nogle af disse efteruddannelsesformer er mere effektive end andre. Studiernes fund viser imidlertid eksempler på, hvordan læreres viden og oplevede behov målrettet kan inddrages, hvilket øvrige studier har fremhævet vigtigheden af (Lochner et al., 2015).

\section{Læringsplatforme i den danske folkeskole - et bud på en fremtidig forskningsagenda}

En af indsigterne fra dette review er, at diskussionerne i litteraturen om digitale læringsplatforme berører en lang række praksisser, processer og aktører, som både selv kan påvirke og også påvirkes af forskellige former for anvendelse og implementering af platforme. I forhold til den danske situation kan vi på baggrund af dette review også konkludere, at der er meget, vi endnu ikke ved, og som der fremadrettet vil være behov for målrettet at generere forskningsbaseret viden om.

Et af de aspekter, som fortsat fremstår underbelyst, er, hvilke nye betingelser for lokalt og platformsdistribueret samarbejde digitale læringsplatforme skaber, og hvordan dette bedst udnyttes. De danske digitale læringsplatforme indeholder bl.a. funktioner, der netop skal understøtte en højere grad af deling og fælles produktion af undervisningsmaterialer, men der mangler endnu danske studier af, hvordan eksisterende skole- og samarbejdskulturer påvirker og påvirkes af disse nye muligheder. Internationale studier har allerede peget på en række potentialer inden for produktion og deling af materialer (Gueudet et al., 2016), men de af Gueudet et al. nævnte studier har indtil videre begrænset sig til særligt matematikdidaktik og har omhandlet matematikdidaktiske platforme. Nationalt bliver der behov for 
flere almendidaktiske studier, der også behandler eventuelle forskelle mellem delingsfunktionerne i de tilgængelige platforme.

Et andet aspekt af platformene er, at de i højere grad end tidligere og på nye måder tilbyder forældre at blive involveret i deres børns skolegang. Et nyligt nationalt studie af forældres brug af Forældreintra har imidlertid vist, at digitale platforme som Forældreintra stiller skjulte krav til forældres akademiske kompetencer, IT-kompetencer og tilgængeligt IT-udstyr, som ikke alle forældre har lige adgang til (Akselvoll, 2017). Ultimativt kan dette betyde, at teknologier som læringsplatforme skaber ulige betingelser for forældres muligheder for at involvere sig $\mathrm{i}$ deres barns skoleliv. Det er vigtigt, at sådanne utilsigtede afledte effekter af implementering af digitale læringsplatforme afdækkes fremtidigt, og at der udvikles tiltag, der kan hindre sådanne uønskede forhold.

Endelig er det bemærkelsesværdigt, at ingen af studierne i reviewet konsekvent undersøger betydningen af beslutningsprocesserne, der ledte frem til beslutning om valget af platform. Særligt i en dansk kontekst har dette været debatteret meget, bl.a. hvilket nyt mulighedsrum, platformene er med til at skabe, og hvordan skolernes pædagogiske personale kan navigere rundt i det.

\section{Konklusion}

I denne artikel har vi vist, at digitale læringsplatforme har potentialer til at understøtte elevers læring, men også at der er væsentlige udfordringer, der går forud for anvendelse af platformene (fx bekymringer i forhold til implementering), og at indfrielsen af disse potentialer forudsætter reflekteret didaktisk anvendelse af platformene. Reviewet har vist, at implementering af digitale læringsplatforme kan involvere og medføre ændringer for mange aktørers arbejdsliv, hvilket er afgørende både at være bevidst om og eksplicit håndtere i implementeringsprocesserne. 


\section{Referencer}

Referencerne mærket (*) er de 21 artikler, der indgår i reviewet.

(*) Abar, C. \& Barbosa, L. (2011). Computer algebra, virtual learning environment and meaningful learning: Is it possible? Acta Didactica Napocensia, 4(1), 31-38.

Akselvoll, M. Ø. (2016). Folkeskole, forceldre og forskelle: Skole-hjemsamarbejde og forceldreinvolvering i et forceldreperspektiv. Roskilde: Roskilde Universitet. (Afhandlinger fra ph.d.-programmet i Hverdagslivets Socialpsykologi).

Biesta, G. J. J. (2011). God uddannelse i målingens tidsalder: Etik, politik, demokrati. Aarhus: Klim.

(*) Blair, R. \& Godsall, L. (2006). One School's Experiences in Implementing E-Portfolios: Lessons learned. Quarterly Review of Distance Education, 7(2), 145-153.

Bundsgaard, J. (2010). Faglighed og digitale læremidler i undervisningen. Dansk Poedagogisk Tidsskrift, (4), 15-24.

(*) Camacho, M. \& Guilana, S. (2011). From personal to social: Learning environments that work. Digital Education Review, (20), 24-36.

(*) Cano, E. V. \& Garcia, L. S. (2013). ICT strategies and tools for the improvement of instructional supervision. The virtual supervision. TOJET: The Turkish Online Journal of Educational Technology, 12(1), 77-87.

(*) De Smet, C., Bourgonjon, J., De Wever, B., Schellens, T. \& Valcke, M. (2012). Researching instructional use and the technology acceptation of learning management systems by secondary school teachers. Computers $\mathcal{E}$ Education, 58(2), 688-696.

(*) Edmunds, B. \& Hartnett, M. (2014). Using a learning management system to personalise learning for primary school students. Journal of Open, Flexible and Distance Learning, 18(1), 11-29.

(*) Friedrich, H. F. \& Horn, A. (2010). Factors influencing pupils' acceptance of an E-learning system for secondary schools. Journal of Educational Computing Research, 42(1), 63-78.

(*) Granic, A. \& Cukusic, M. (2011). Usability testing and expert inspections complemented by educational evaluation: A case study of an e-learning platform. Journal of Educational Technology \& Society, 14(2), 107-123.

Gueudet, G., Pepin, B., Sabra, H. \& Trouche, L. (2016). Collective design of an e-textbook: Teachers' collective documentation. Journal of Mathematics Teacher Education, 19(2), 187-203.

(*) Hamdy, A. A. (2013). From Physical Benchmarks to Mental Benchmarks: A four dimensions dynamic model to assure the quality of instructional activities in electronic and virtual learning environments. The Turkish Online Journal of Distance Education, 14(2), 267-280.

Johansson, A. \& Glauman, M. (2014). Leveraging ICT for a world-class education system. Arthur D. Little.

Johnson, L., Adams Becker, S. \& Hall, C. (2015). 2015 NMC technology outlook for scandiavian schools - a horizon project regional report. Austin, Texas: The New Media Consortium.

KL (2016). Brugerportalsinitiativet. Kravspecifikation til læringsplatform. version 1.o. 
KL, Undervisningsministeriet, Finansministeriet, \& Ministeriet for Børn, Ligestilling, Integration og Sociale Forhold Økonomi- og Indenrigsministeriet (2014). Aftale om konkretisering af det foelles brugerportalsinitiativ for folkeskolen.

(*) Liu, F. \& Cavanaugh, C. (2011). High enrollment course success factors in virtual school: Factors influencing student academic achievement. International Journal on ELearning, 10(4), 393-418.

(*) Lochner, B., Conrad, R. \& Graham, E. (2015). Secondary teachers' concerns in adopting learning management systems: A U.S. perspective. TechTrends, $59,62-70$.

(*) Lu, J. \& Law, N. W. Y. (2012). Understanding collaborative learning behavior from moodle log data. Interactive Learning Environments, 2O(5), 451-466.

(*) McGill, T. J. \& Hobbs, V. J. (2008). How students and instructors using a virtual learning environment perceive the fit between technology and task. Journal of Computer Assisted Learning, 24(3), 191-202.

(*) Nasser, R., Cherif, M. \& Romanowski, M. (2011). Factors that impact student usage of the learning management system in Qatari schools. The International Review of Research in Open and Distributed Learning, 12(6), 39-62.

(*) Nokelainen, P. (2006). An empirical assessment of pedagogical usability criteria for digital learning material with elementary school students. Journal of Educational Technology \& Society, 9(2), 178-197.

(*) Papadakis, S., Dovros, N., Paschalis, G. \& Rossiou, E. (2012). Integrating lms's in the educational process: Greek teachers initial perceptions about lams. The Turkish Online Journal of Distance Education, 13(4), 55-75.

Pogorskiy, E. (2015). Using personalisation to improve the effectiveness of global educational projects. E-Learning and Digital Media, 12(1), 57-67.

(*) Psycharis, S., Chalatzoglidis, G. \& Kalogiannakis, M. (2013). Moodle as a learning environment in promoting conceptual understanding for secondary school students. Eurasia Journal of Mathematics, Science and Technology Education, 9(1), 11-21.

(*) Selwyn, N., Banaji, S., Hadjithoma-Garstka, C. \& Clark, W. (2011). Providing a platform for parents? exploring the nature of parental engagement with school learning platforms. Journal of Computer Assisted Learning, 27(4), 314-323.

(*) Selwyn, N. (2011). 'It's all about standardisation' - exploring the digital (re)configuration of school management and administration. Cambridge Journal of Education, 41(4), 473-488.

(*) Tay, L. Y., Lim, C. P., Nair, S. S. \& Lim, S. K. (2014). Online software applications for learning: Observations from an elementary school. Educational Media International, 51(2), 146-161.

(*) Underwood, J. D. M., \& Stiller, J. (2014). Does knowing lead to doing in the case of learning platforms? Teachers and Teaching, 2O(2), 229-246.

Watson, W. R. \& Watson, S. L. (2007). An argument for clarity: What are learning management systems, what are they not, and what should they become? TechTrends, 51(2), 28-34. 
Learning Tech - Tidsskrift for læremidler, didaktik og teknologi Udgives af Læremiddel.dk

Learning Tech er et forskningstidsskrift, hvor alle artikler er forskerbedømt i form af dobbeltblindt peer review. Tidsskriftet bringer artikler, der rammer genstandsfeltet mellem læremidler, didaktik og teknologi, og hensigten er at spille en betydelig rolle som platform for den voksende skandinaviske læremiddelforskning.

\section{Redaktion}

Stig Toke Gissel, UCL Erhvervsakademi og Professionshøjskole (ansvarshavende redaktør)

Bettina Buch, Professionshøjskolen Absalon

Hildegunn Juulsgaard Johannesen, University College Syd

René Boyer Christiansen, Professionshøjskolen Absalon

Stine Reinholdt Hansen, UCL Erhvervsakademi og Professionshøjskole

Thomas R.S. Albrechtsen, University College Syd

\section{Redaktionssekretær}

Trine Ellegaard, UCL Erhvervsakademi og Professionshøjskole

\section{Temaredaktion}

Ane Qvortrup, Syddansk Universitet

Stig Toke Gissel, UCL Erhvervsakademi og Professionshøjskole

Morten Misfeldt, Aalborg Universitet

Jens Jørgen Hansen, Syddansk Universitet

\section{Design og grafisk tilrettelæggelse}

Trefold - grafisk design og kommunikation

\section{Tryk}

Narayana Press, Gylling

ISSN 2445-7981 (Tryk)

ISSN 2445-6810 (Online)

\section{Rettigheder}

(C) 2019 Læremiddel.dk og forfatterne

\section{Kontakt}

Læremiddel.dk, Niels Bohrs Allé 1, 5230 Odense M

https://learningtech.laeremiddel.dk

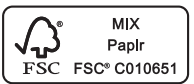

